\title{
Assessment of Imja Glacier Lake outburst Flood (GLOF) Risk in Dudh Koshi River Basin using Remote Sensing Techniques
}

\author{
Kamal P. Budhathoki ${ }^{1}$, O. R. Bajracharya ${ }^{1}$ \& B.K.Pokharel ${ }^{1}$ \\ 1 Department of Hydrology and Meteorology, Babarmahal, GPO Box 406, Kathmandu, Nepal
}

\begin{abstract}
Glacier lakes are common phenomena in the Himalaya region of Nepal. Glacier lake outburst floods have repeatedly caused the death tolls and severe damage to downstream infrastructures. In Himalayas, a vital uncertainty about the glacier lake hazard potential still exists, thereby the effects of accelerating rates of glacier retreat and expansion of Glacier Lake could be the wake of recent global warming and resulting climatic changes. The paper, first describes the general different-level approach upon which the study is based. Then, in the methodological part, applicable remote sensing techniques, geographic information system (GIS) and statistical methods are presented. Observed data of lake area, volume, and depth having similar lake characteristics reported in the different literature are used to develop empirical equations by using statistical methods. The values of $\mathrm{r}^{2}$ (coefficient of determination) - obtained are very high $\left(\mathrm{r}^{2}=0.939\right.$ for depth - area relationship and $\mathrm{r}^{2}=0.990$ for volume - area relationship). The comparison of the empirical expression clearly indicated that there is more than $90 \%$ variation in the dependent variable, lake volume, as explained by the linear regressions in both cases. Area of Imja glacier lake for different years are determined from the available satellite imagery and volume of the Imja glacier lake are estimated using the expression: $\mathbf{V}=0.094 \mathbf{A}^{1.453}$.developed from linear regression analysis of the observed data. Similarly, mean depth can be estimated by using the expression: $\mathbf{D}=0.94 \mathbf{A}^{0.452}$.
\end{abstract}

After the preparation of maps and data, a scheme of decision criteria for the evaluation of hazard potential of Imja glacier lake is established. A list of decision criteria is a documented set of factors that are used to examine and compare for evaluating the hazard potential of a glacier lake. The empirical scores are given in terms of hazard magnitude for hazard rating. Analysis of Imja glacier lake based on the empirical scoring system clearly indicated that GLOF risk of the possible outburst from Imja glacier lake is MODERATE. A systematic application of remote sensing based methods for glacier lake outburst flood risk assessment is applicable and thus recommended.

Keywords: Glacier lake outburst, remote sensing, risk assessment, hazard potential, empirical parameters, climate change

\section{INTRODUCTION}

Climate change studies showed that the Himalayan glaciers have been receding since last 150 years.
The studies also reflected that Himalayan glaciers have undergone various stages of retreat, advance and standstill in those years, while the rate of glacier retreat has been more rapid since 1990's. 
Results of such phenomena have been responsible for the development and expansion of glacier lakes in the Himalayas. Most of the glacier lakes in Nepal Himalaya are likely to have begun to develop in the 1950s (Watanabe et al., 1994; Sakai, 1995). Many of the glacier lakes are formed on the debris-covered areas of glaciers. Some of the glaciers have higher rates of retreat due to which the glacier lakes are increasing at unexpected rates. The process of fast glacier retreat and expansion of glacier lakes could be the wake of recent global warming and leading climatic changes.

Glacier lakes that are dammed with unconsolidated weak natural moraines pose potential risk of their catastrophic failure, causing a huge flash flood in the downstream areas commonly known as Glacier Lake Outburst Flood (GLOF). GLOF is a relatively new type of natural hazard in the Himalayan region which has emerged as consequence of ongoing climate change. Glacier lakes drew the attention of many researchers, scientists and concerned institutions and abroad following the outburst of Dig Tsho Lake in eastern Nepal on 4 August 1985. In the past couple of decades, several lakes caused outburst floods affecting human lives and infrastructure (Vuichard and Zimmermann 1987; Yongjian and Jingshi 1992; Hanisch et al. 1996). Past field investigation have identified that few glacier lakes are potentially dangerous and recommended to adopt appropriate mitigation measures to minimize the possible damage in the event of a GLOF. Most glacier lakes have not yet been identified or studied because of their remote locations.

The study especially focused on the use of remote sensing technology and other methods applied in Imja glacier lake for potential risk assessment. Imja lake is one of the head sources of Dudh Koshi river. There are many glacier lakes in Dudh Koshi river basin. Imja glacier lake is a bigger one and few of them are found to be a considerable size. Data used in the study were high and low resolution satellite data and past study reports. The paper first describes the general different-level approach upon which the study is based. Then, in the methodological part, applicable remote sensing techniques, geographic information system (GIS) and statistical methods are presented. After the preparation of maps and data, a scheme of decision criteria (ICIMOD, 2001; Huggel et al. 2002 and RGSL, NEA. 2004) for the evaluation of hazard potential of Imja glacier lake is discussed. It is crucial and challenges to judge and evaluate the potential risk assessment without having the detailed geophysical field investigation works.

\subsection{SOCIOECONOMIC IMPACTS OF GLACIER LAKE OUTBURST FLOODS}

GLOF events are severe geo-morphological hazards and their floodwaters can wreak havoc on all human structures located on their path. Much of the damage created during GLOF events is associated with the large amounts of debris that accompany the floodwaters. Damage to settlements and farmland can take place at very great distances from the outburst source (WECS 1987b).

Direct and indirect sociological impacts are the loss of human lives and the agricultural lands when converted to debris filled lands due to which villages have to be shifted to other safe locations. Based on the past GLOF events, many reports coated that once every three to ten years, a GLOF has occurred in Nepal with varying degrees of socioeconomic impact. Brief studies of GLOFs throughout the world showed that there are no simple direct means of estimating the recurrence of GLOFs. Various GLOF events have occurred periodically over the past in Nepal. Most of them were not recorded. An early overview of glacier 
lake outburst hazards in Nepal was given by Ives (1986). Few of them were documented based on information from inhabitants living in the Himalayan highland along the river courses. Many of these events originated in Tibet autonomous region of China outside the political boundary of Nepal.

As a consequence of the GLOF events, attention was drawn to large glacier lakes of Nepal and Tibet. Few rivers of Nepal have their origin at Tibet, such as Arun river, Tama koshi, Sun Koshi, Gandaki and Karnali etc. Highly awareness and the realization of the destructive nature of GLOF, the necessities of detail investigation of potentially dangerous lakes would come into higher priority. International practices had shown that if preventive measures are taken in time in order to avoid likelihood disastrous flood that could occur from Glacier Lake, lots of lives and properties could be saved. The first mitigation program against GLOF in Nepal was undertaken in Tsho Rolpa, the largest glacier lake in Nepal. Selection of a mitigation measure against GLOF requires in depth knowledge in different aspects of the glacier lakes.

\subsection{IMPORTANCE OF GLOF RISK ASSESSMENT IN DUDH KOSHI RIVER BASIN}

The study of glacier lakes is very imperative for the planning and implementation of any socioeconomic and water resource development project. Past records reveal that glacier lakes have created devastating floods and damage to major constructions and infrastructure.

There are a lot of hydropower potential sites as well as thousands hectors of cultivated lands along the Dudh Koshi river courses. Dudh Koshi basin has of many glaciated sub- basin.
A sudden burst of a glacier lake in any sub-basin may cause loss of lives and damage to the villages, cultivated lands and infrastructures (hydropower, irrigation sites etc.) situated downstream. Debris deposited by flood, landslide and temporary damming due to flood can cause the major to the people living hindrances downstream.

A sudden burst of Imja lake will cause extensive damage along the entire length of the Imja Khola/ Dudh Koshi valleys down to the confluence with Sun Koshi, an overall distance of about $90 \mathrm{~km}$. Study showed that (Shrestha, 2007) a minimum estimated outburst flood from Imja Glacier Lake would affect significant changes on the local topography and the river courses. In addition, the low lying terraces of Dingboche village, Shanjo Kalka and the hotels and lodges along trekking routes to Chhukhung, would be washed away. Tsuro Og, Orsho, Pangboche, Phunki, Thumbug, Nyambua, Phakdingma, etc. are the villages situated within $32 \mathrm{~km}$ downstream of the lake and these villages are most vulnerable to possible GLOF from Imja Glacier Lake (Braun and Fiener, 1995). The study was carried out by using hydrodynamic model coupled with extensive use of geo-informatics. The model outputs provide information on flood arrival time, discharge and depth at different locations in the valley which could improve the understanding on the effects of a GLOF from Imja Lake.

\section{PHYSICAL SETTING OF IMJA GLACIER LAKE IN DUDH KOSHI BASIN}

Imja Lake is located in Solukhumbu district, Sagarmatha Zone, Eastern Development Region of Nepal at aerial distances of about $163 \mathrm{~km}$ from Kathmandu and about $6 \mathrm{~km}$ south of Mount Everest (Figure 1). The lake is an intra-glacier lake in the Imja glacier and its two major tributary 
glaciers are Lhotse Shar glacier flowing from northeast and Ambulapcha glacier from south. It is located south east of Chokarma Tsho and northeast of Ambulapcha Tsho. The valley opens in the southwest. The latitude and longitude of the lake are $27^{\circ} 59^{\prime} 17^{\prime} \mathrm{N}$ and $86^{\circ} 55^{\prime} 31^{\prime \prime} \mathrm{E}$. The lake is situated at an elevation of approximately 5010 $\mathrm{m}$ (a.m.s.l). The major drainage system of upper Imja khola basin is shown in figure 2. There is only one outlet flowing through the southern part of the end moraine dam. The melt water drains into the lake from en-glacier channels (WECS, 1991). The lake collects water from drainage basin area of $37.67 \mathrm{~km} 2$ of which $69 \%$ is glacier covered. The glacier lake is strongly influenced by the subtropical monsoon climate (June-September), which produces a pronounced summer precipitation, greater than $80 \%$ of annual total.

The moraine dam is composed of unconsolidated clay, silt, sand, gravel and boulder, making the dam very unstable. The lateral moraine surfaces of Imja
Lake are very steep and the loose surface materials continuously falling into the lake surface. The end moraine is relatively lower than the later moraines. The end moraine rises sharply to the height of approximately $100 \mathrm{~m}$ from the riverbed level of Imja Khola (Yamada, 1998).

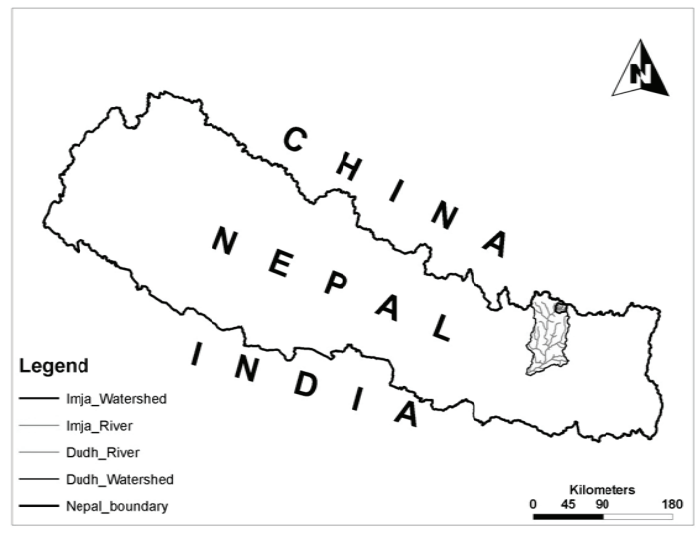

Figure 1:

Location map of the Dudh Koshi basin

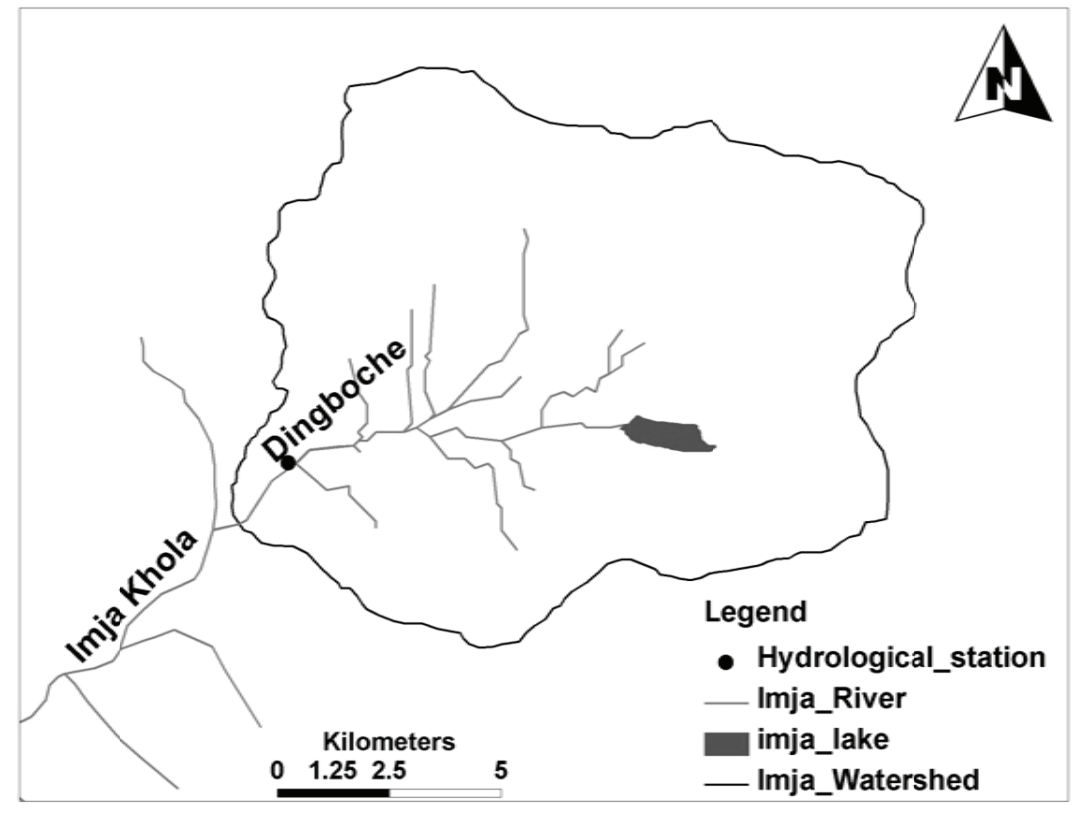

Figure 2: The river system in upper Imja Khola watershed 


\section{MATERIALS AND METHODOLOGY}

The basic materials required for this study are satellite images, aerial photographs and past study reports. All the components of cryospheric region cannot be measured directly from space but some parameters such as glacier lake, glacier area, terminus position, transient snowlines and surface elevations can be extracted from airborne and space-borne scanning. Medium resolution satellite data $(10$ - $90 \mathrm{~m})$ have become available for cryospheric studies since the early 1970s, with the launch of new spaceborne sensors: Landsat Multispectral Scanner (MSS), Landsat Thematic Mapper (TM) Enhanced Thematic Mapper Plus $(\mathrm{ETM}+)$ and the Advanced Visible and Near Infrared Radiometer type 2 (ALOS: AVNIR-2). Advanced Land Observing Satellite (ALOS) launched on January 2006 by the Japanese Earth observing satellite data such as the Advanced Visible and Near Infrared Radiometer type 2 (AVNIR-2). Images of course resolution (Landsat MSS, TM and ETM + of 1970s, 80s, 90s and 2000) and image of AVNIR-2 $(10 \mathrm{~m})$ of 2008 were used for mapping, monitoring and assessing the GLOF risk of Imja glacier lake. The activity of this lake in terms of hazard score is developed by using the logical calculation in the GIS, statistical analysis, decision criteria and empirical scoring.

\subsection{SATELLITE IMAGES AND IMAGE CLASSIFICATION}

Remote-sensing data like MSS, TM, ETM+, ALOS (AVNIR) for different dates are used to prepare the maps of Imja glacier lake for GLOF risk assessment. Due to higher spatial resolutions and freely available, TM and ETM image are used as the data source with least cloud cover. The combination of digital satellite data and the Digital Elevation Model (DEM) is used for better and more accurate results for the lake area measurement. Different dates are used to monitor the changes. The generated DEM combined with satellite images helped in deciding for discrimination of features and land-cover types for better perspective viewing. DEM itself is used to create various data sets on the lake and glaciers (e.g., slope, aspect). DEM should be compatible with and of reliable quality when compared with other data sets. The satellite images draped over the DEM for better interpretation work.

For lake detection, the following techniques are based on optical panchromatic and multispectral remotely sensed data. The detection of glacier lake area using multispectral imagery involves discriminating between water and other surface types. Delineating surface water can be achieved using the spectral reflectance differences. Water strongly absorbs in the near- and middle-infrared wavelengths. Vegetation and soil, in contrast, have higher reflectance in the near and middleinfrared wave lengths, hence water bodies appear dark compared to their surroundings when using these wavelengths (Pietroniro and Leconte 2000). Applying the idea of two spectral channels with maximum reflectance difference for an object (i.e., water), a blue channel (maximum reflectance of water) and a near-infrared (NIR) channel (minimum reflectance of water) were chosen.

Different image enhancement techniques were used to identify the lake and the glaciers contact with them. In this regard visual interpretation methods with the knowledge of image interpretation keys: color, tone, texture, pattern and association, shape, shadow, etc and experience of the terrain conditions played a vital role for glacier lake risk assessment tasks. Analyzing by different spectral band combinations in false color composite (FCC) and in individual spectral bands helped to identify the surrounding situation of the glacier lake. 
Different color composite images were used to simplify the different land-cover features. Water bodies were first separated from snow, ice and vegetation by applying several types of supervise classification methods. Misclassified areas of shadow were identified and interpolate the values based on past data and on field knowledge of topography of glacierized area. Frozen water detected by the automatic classification as snow, so these areas were also added manually. Glaciers, snow cover hampered the demarcation of lake area, especially in the shadowing region of the basin.
Multi-temporal data sets are an invaluable source for the comparison with past, in between and present situations. For instance, a number of satellite data before and recent enabled mapping and better understanding of mother glaciers, glacier lake and its changes with degrading nature. Thus, multitemporal applications are of particular important for monitoring and assessing glacier lake outburst flood risk. Accurate co-registration of the repeat data, i.e. identical ground co-ordinates for identical (stable) terrain points, is a crucial prerequisite of any image change detection within a certain span of time (Figure 3).

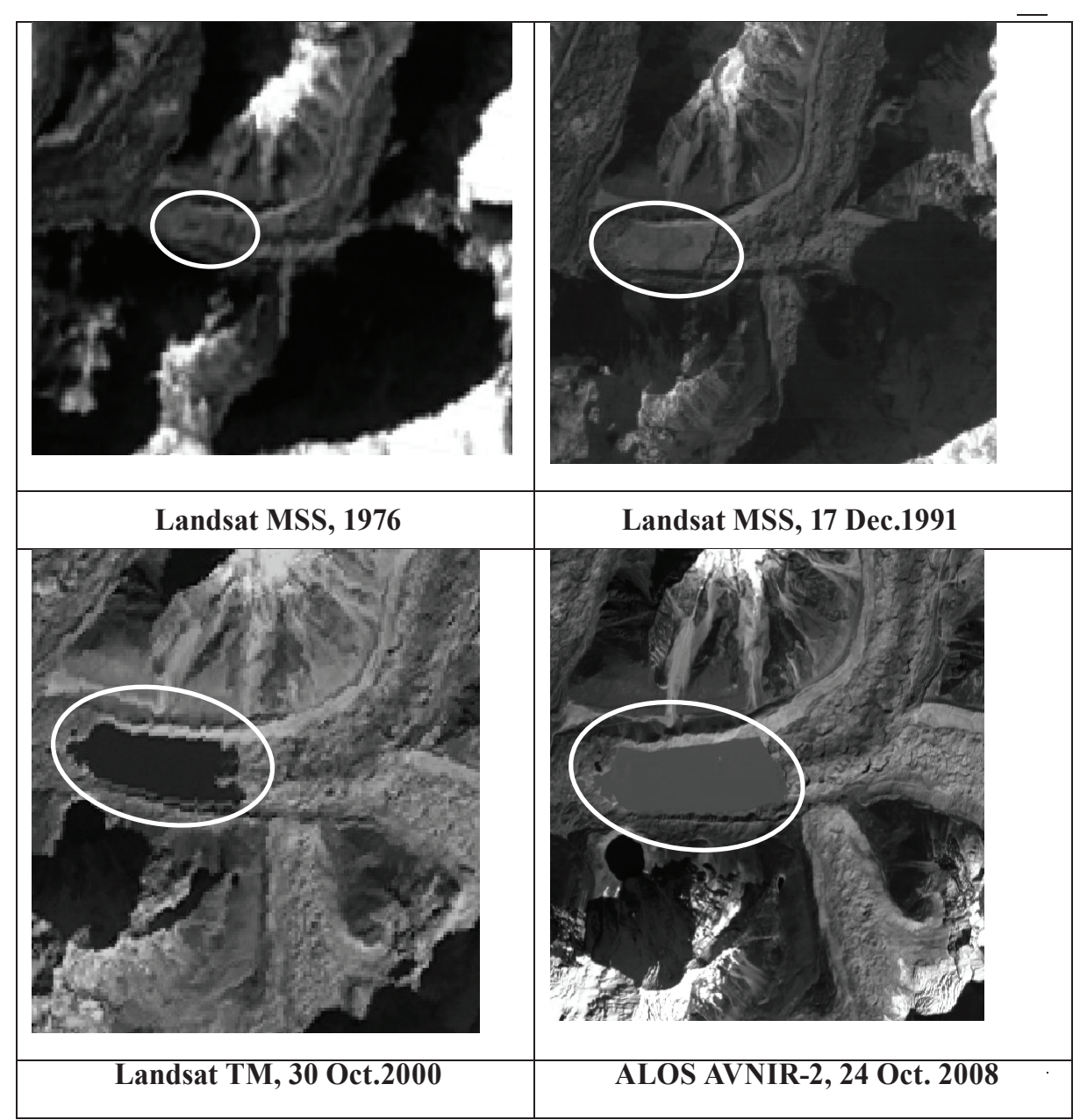

Figure 3: Imagery of the Imja Glacier Lake area of different dates 


\section{MAPPING, MONITORING AND COMPUTING VOLUME OF IMJA GLACIER LAKE}

The longitudinal growth of the lakes is not only due to the melting of the cliff-shaped terminus but with the collapsing of the cliff (calving process) together the degradation processes in and on the surface of end and lateral moraines. For the delineation of the exact contact points between the lakes and the terminus of the mother glacier, the high resolution imageries are used. The study was mainly emphasized on the time series mapping of glacier lake and monitoring of the surface area changing. Shifting backward of the upstream end of the lake and changing on the end moraine morphology at the surface of ice cored-debris covered end moraine in front are remarkable causes to expand the lake.

\subsection{MAPPING AND MONITORING OF GLACIER LAKES}

The mapping and monitoring of glacier lake are totally based on different types and dates of satellite images, secondary data source and aerial photograph. The data set images of 1980s, 1990s, 2000 and 2008 of Dudh Koshi basin were used. Least snow cover and cloud free satellite images were selected for lake area measurement. Least snow cover in the Himalayas occurs generally in the summer season (May-September). But during this season, monsoon clouds will block the views. If snow precipitation is late in the year, winter images are also suitable except for the problem of long relief shadows in the high mountain regions. The frozen lake always has a level at the toe of the Imja glacier tongue. Mapping of the lake was carried out visually as well as digitally by the help of DEM. In both the visual interpretation and digital feature extraction techniques, the analyst's experience and adequate field knowledge were applied. The glacier lake on each image was delineated by the help of DEM. The 3D map of Imja glacier lake based on satellite image of 2008 is as shown in figure 4.

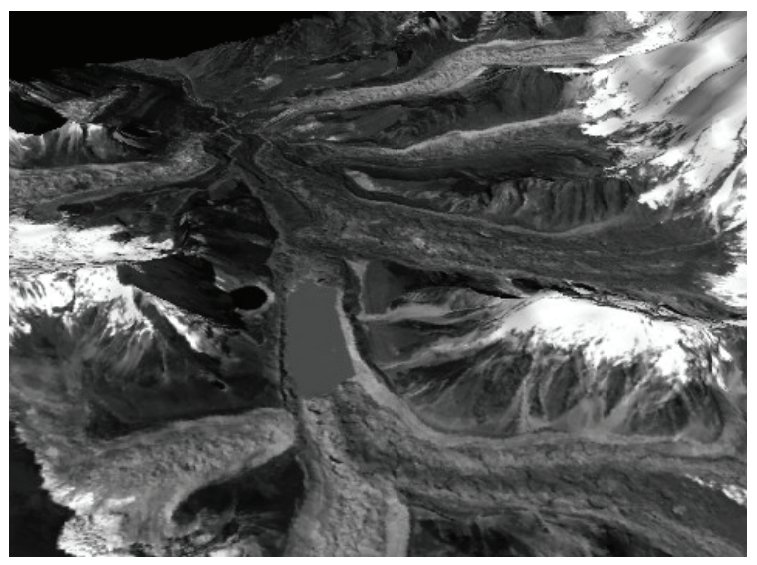

Figure 4: Downstream view of 3D image of upper Imja river basin (24 Oct, 2008)

\subsection{EMPIRICAL METHODS FOR LAKE VOLUME ESTIMATION}

Surface area of the lake could be extracted from remotely sensed data. However, glacier lake volume rather than area is essential to estimate potential peak discharge for a possible outburst. There is no realistic way to directly derive the volume from optical remote sensing data despite a number of efforts to perform mapping of surface water and depth measurements from satellite image (Benny and Dawson 1983). The reliability of these remote sensing based bathymetric studies depends on finding a significant relationship between water depth and reflected energy (Baban 1993). Large number of glacier lakes in poorly known high mountain areas makes this approach unfeasible to calculate the volume, so an empirical approach is chosen instead by Huggel et al. (2002) for the Swiss Alps. They used the empirical models for outburst characteristics by computing lake volume and outburst discharge. Similar attempt has been made to develop the 
empirical relation for computing the volume of glacier lakes. Hence, observed data of lake area, volume, and depth reported in the different literature (Table 1) are compiled (Swiss Alps,
TAR and Nepal Himalayas), and the functional empirical relationship are developed for volume - area and area - depth by applying statistical regression analysis.

Table 1: Compiled data on glacier lake area, volume and mean depth

\begin{tabular}{|c|c|c|c|c|c|c|}
\hline S.No & $\begin{array}{c}\text { Name of glacier } \\
\text { lake }\end{array}$ & Area $\left(M^{2}\right)$ & Volume $\left(M^{3}\right)$ & $\begin{array}{l}\text { Mean depth } \\
\text { (M) }\end{array}$ & Type of lake & Reference \\
\hline 1 & Gruben Lake 5 & 10000 & 50000 & 5 & Thermokarst & Teysseire 1999 \\
\hline 2 & Gruben Lake 1 & 23000 & 240000 & 10.4 & Moraine-dammed & KÍääb 1996 \\
\hline 3 & Lac d' Arsine & 59000 & 800000 & 13.6 & Moraine-dammed & Vallon 1989 \\
\hline 4 & Nostetuko lake & 262200 & 7500000 & 28.6 & Moraine-dammed & Clague \&Evans 1994 \\
\hline 5 & Gjanupsvatn & 600000 & 20000000 & 33.3 & Ice-dammed & Costa \& Schuster 1988 \\
\hline 6 & Abmachimai Cho & 565000 & 19400000 & 34.3 & Moraine-dammed & Meon \&Schwarz 1993 \\
\hline 7 & Gokyo Lake & 400000 & 21000000 & 40 & Ice-dammed & WECS 1986 \\
\hline 8 & Gelhaipu Cho & 580000 & 25500000 & 42 & Moraine-dammed & Xu \& Feng 1994 \\
\hline 9 & Thulagi & 760000 & 31800000 & 42 & Moraine-dammed & WECS \& JICA 1996 \\
\hline 10 & Lower Barun & 600000 & 28000000 & 47 & Moraine-dammed & WECS 1993 \\
\hline 11 & Imja Tsho & 750000 & 33480000 & 48 & Moraine-dammed & DHM 1999 \\
\hline 12 & Tsho Rolpa & 1390000 & 76600000 & 55.1 & Moraine-dammed & WECS 1994 \\
\hline 13 & Quangzongk Cho & 760000 & 21700000 & 29 & Moraine-dammed & Xu \& Feng 1994 \\
\hline
\end{tabular}

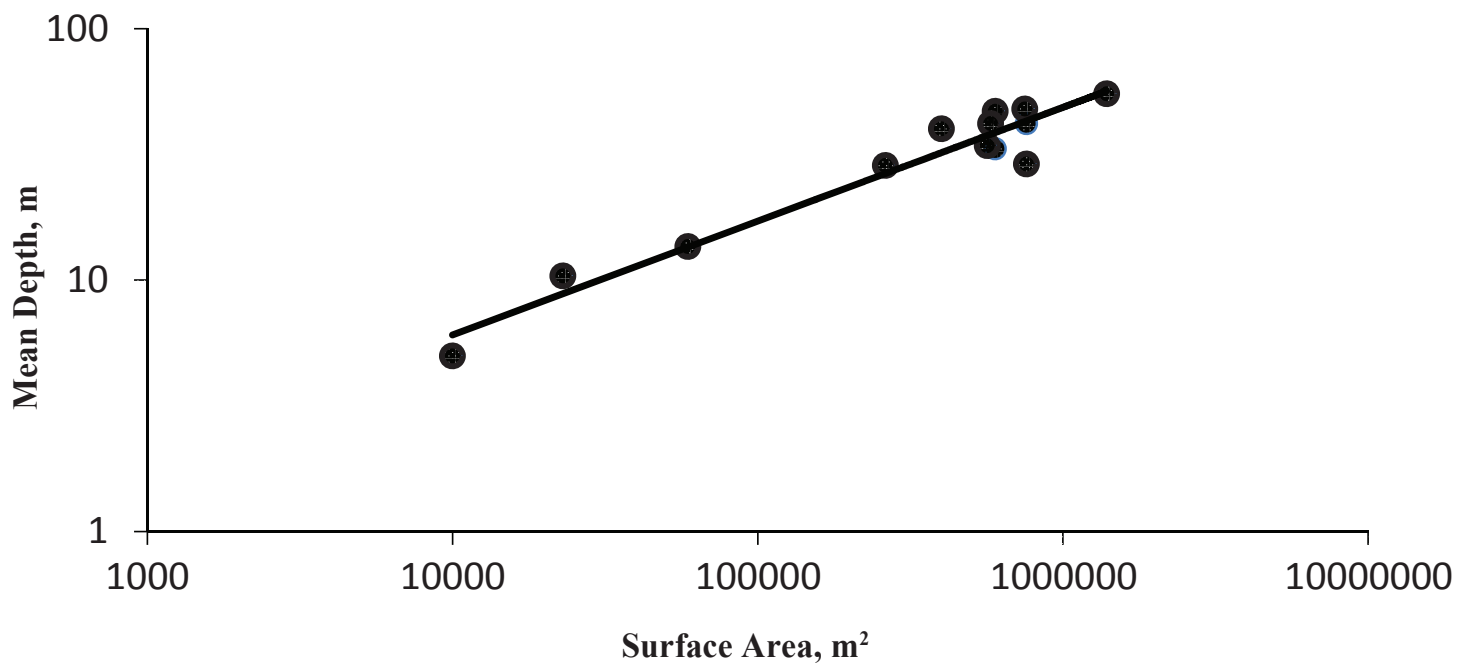

Figure 5: Regression between mean depth and area for ice - and moraine - dammed lakes

The regression analysis between area (A) and mean depth (D), yields the following equation

$\mathbf{D}=0.094 \mathbf{A}^{0.452}$-----------(Eqn.1), $\quad$ where $\mathrm{r}^{2}=0.939$ 


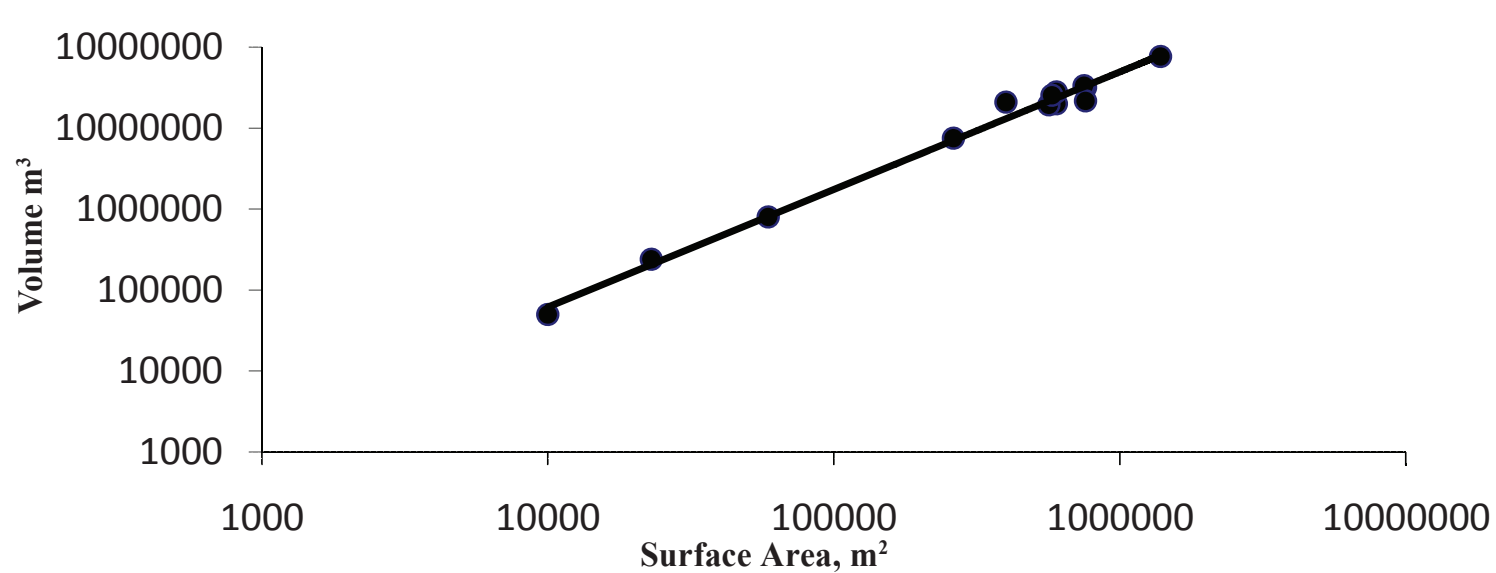

Figure 6: Regression between volume and area for ice - and moraine - dammed lakes

The glacier lake volume (V) can be estimated using following regression equation.

$$
\mathbf{V}=0.094 \mathbf{A}^{1.453}
$$

A similar expression was defined by the Canadian Inland Water Directorate for glacier-dammed lakes (Evans 1986a):

$$
\mathbf{V}=0.035 \mathbf{A}^{1.5}
$$

\subsection{SURFACE AREA AND VOLUME COMPUTATION}

Imja Glacier Lake started to grow with size rapidly around year 1963. Surface area of Imja Glacier Lake was found increasing up to the date 24 October 2008 (Table 2). Using regression equation 2, volume of Imja glacier lake has been estimated. Glacier Lake was found increasing up to the date 24 October 2008 (Table 3). Using regression equation 2, volume of Imja glacier lake has been estimated.

\subsection{INTERPRETATION OF THE RESULT}

The values of $\mathrm{r}^{2}$ (coefficient of determination) obtained are very high $\left(\mathrm{r}^{2}=0.939\right.$ for depth - area relationship and $r^{2}=0.990$ for volume - area Journal of Hydrology and Meteorology, Vol. 7, No. 1 relationship). The comparison of the empirical expression clearly indicated that there is more than $90 \%$ variation in the dependent variable, (lake volume,) as explained by the linear regressions.

The results of an analysis of variance (ANOVA) showed a large regression sum of squares (5.650 for depth-area and 58.310 for volume- area) in comparison to the residual sum of squares $(0.365$ depth-area and 0.564 for volume-area ) indicating the model accounts for most of variation in the dependent variable. Very high residual sum of squares indicate that the model fails to explain a lot of the variation in the dependent variable, and hence necessary to look for additional factors that help account for a higher proportion of the variation in the dependent variable. The significance value of the F statistic is zero (smaller than 0.05 ) then the independent variables do a 
good job explaining the variation in the dependent variable.

Water volume contain in the lake is one of the most important factors for the potential hazard criteria of GLOF. Very little information and unavailability of required data of the study area, the empirical relation played a significant role for computing the volume from satellite derived area of glacier lakes. This method uses the area $(A)$ of a lake, which is easily measured accurately in the satellite imagery and to convert to a volume $(V)$ using the expression: $\mathbf{V}=0.094 \mathbf{A}^{1.453}$. The estimated volumes (Table 3) of Imja glacier lake at different dates are thought to be accurate to the level of $\pm \mathbf{1 5} \%$ after validation with few observed data.

Table 2: Surface area and computed volume of Imja Glacier Lake

\begin{tabular}{|c|c|c|c|c|}
\hline Year & Area, $\mathbf{k m}^{2}$ & Area, $\mathrm{m}^{2}$ & Volume, $\mathrm{m}^{3}$ & Source \\
\hline 1963 & 0.03 & 30000 & 297788 & $\begin{array}{l}\text { Prof. Fritz Muller, member of Swiss Everest/Lhotse expedition, 1956; } \\
\text { topo map (1978) \& surveyed (1956-1963) }\end{array}$ \\
\hline 1975 & 0.3 & 300000 & 8431560 & $\begin{array}{l}\text { Aerial oblique photograph, Japanese Glaciological Expedition of Nepal } \\
\text { (GEN),1975 }\end{array}$ \\
\hline 1978 & 0.36 & 360000 & 10986999 & $\begin{array}{l}\text { Aerial oblique photograph, Japanese Glaciological Expedition of Nepal } \\
\text { (GEN), } 1978\end{array}$ \\
\hline 1984 & 0.47 & 470000 & 16181320 & $\begin{array}{l}\text { Vertical photograph (National Geographic Magazine, 1984), Landsat } \\
\text { image, } 29 \text { Oct. } 1984\end{array}$ \\
\hline 1986 & 0.53 & 530000 & 19265328 & SPOT 1, HRV 1 Image, 23rd March 1986 \\
\hline 1991 & 0.652 & 652000 & 26026476 & $\begin{array}{l}\text { Landsat TM, Dec 1991( DHM and Central Dept of Hydrology and Me- } \\
\text { teorology (CDHM), TU, 1998) }\end{array}$ \\
\hline 1992 & 0.685 & 685000 & 27960862 & $\begin{array}{l}\text { Aerial Photograph, Topographical Survey Branch, Survey Department, } \\
\text { HMG/Nepal, WECS, } 1992\end{array}$ \\
\hline 1996 & 0.721 & 721000 & 30119646 & Topographical map, 1996, and field survey (DHM \& CDHM, TU) \\
\hline 1997 & 0.74 & 740000 & 31278960 & DHM/Nepal \& Hokkaido University/Japan, March 1999 \\
\hline 1999 & 0.75 & 750000 & 31894574 & DHM, 1999 \\
\hline 2001 & 0.788 & 788000 & 34267618 & Dr. Tomomi Yamada, ASTER AVN color composite \\
\hline 2004 & 0.889 & 889000 & 40825660 & ASTER AVN, 21Nov.2004 (DHM) \\
\hline 2008 & 0.9595 & 959500 & 45609694 & ALOS AVNIR-2, 24 Oct. 2008 (DHM) \\
\hline
\end{tabular}

\section{DECISION CRITERIA FOR IDENTIFICATION OF POTENTIAL DANGER}

The glacier lakes located away from presentday glaciers and the downstream banks are usually made of bedrock or covered with a thinner layer of loose sediment generally do not pose an outburst danger. On the other hand, the moraine-dammed glacier lakes have the potential for bursting. The advance and retreat of the glacier affect the hydrological regime between the present day glacier and the lake dammed by the moraines. Sudden natural phenomena with a direct effect on a lake, like ice avalanches or rock and lateral moraine material collapsing on a lake, cause moraine breaches with subsequent lake outburst events. Such phenomena have been well known in the past in several cases of moraine-dammed lakes, although the mechanisms that play are not fully understood. 
Field investigation and inventory in middle section of the Tibetan Himalayas showed that the dangerous glacier lakes exhibit the well closed basins with high and narrow moraine ridges and contact with the mother glaciers which could really be marked a potential outburst danger. The major triggers of the outburst are (i) ice avalanche from advanced glacier tongue with a volume usually at millions of cubic meters and (ii) ablation activities of dead ice beneath moraine ridges (Xu and Feng, 1994).

It is huge and very difficult task to establish a set of criteria without doing more detailed investigation on geo-technical, glaciological and geo-morphological as well as hydrological aspects in and around the potential dangerous glacier lake area. Unfortunately, there is no common agreed set of indicators to assess the risk of GLOFs from young, moraine dammed glacier lakes (Grabs and Hanisch, 1993). However, the criteria developed by ICIMOD for identifying the potentially dangerous glacier lakes are prerequisite for hazard/scoring system for moraine-dammed lake outburst potential. The decision criteria for evaluating a glacier lake's hazard potential in the Himalayas are mainly outlined briefly as:

1. Surface area and volume of water stored;

2. Lake in contact with active ice body of a glacier (other than parent glacier);

3. Steeper slope of the moraine walls and mass movement or potential mass movement in the inner slope and/or outer slope

4. Risk of ice calving from glacier snout/ice cliff

5. Freeboard relative to the lake water level

6. Rock fall/ice avalanche in the periphery of the lake

7. Evidence of strong dam seepage
8. Moraine dam condition (ice-cored/ thermokarst)

9. Supra- and en-glacier channel

10. Complex/compound threat (height of glacier snout, glacier with deep crevasses, slopes, orientation, dipping, etc)

Based on the above hazard/ scoring indicators/ criteria, following sets of decision criteria (Table 3 ) were prepared and applied to Imja glacier lake, because the lake has been subjected to closer examination. Two different scale levels rather than three (Huggel et al, 2002) exemplify the basic approach of this study:

Level 1: The first level comprises the basic detection of Imja glacier lake in Imja basin and its high spatial and temporal variability from a powerful tool like space-borne remote sensing techniques.

Level 2: This level assesses the hazard potential of the lake detected in Level 1. Level 1 was complemented by information about the related hazards. Therefore, in Level2, image interpretation, analysis and GIS modeling based on multisource data such as high resolution satellite imagery (AVNIR: $10 \mathrm{~m}$ ) and digital elevation models were applied.

Level 3: This level is mainly concerned with detailed investigations of lake recognized through Levels 1 and 2 to have a significant hazard potential. Typically, such investigations are concerned with one specific lake and apply very high resolution remote sensing data, geophysical studies, and other field work. Application of Level 3 is usually a prerequisite for carrying out on-site mitigation measures and is not applicable in the present risk assessment of glacier lake outburst. 
Table 3: Decesion criteria for identifying potentially dangerous glacier lake

\begin{tabular}{|l|c|l|}
\hline \multicolumn{1}{|c|}{ Decision criteria } & Scale level & \multicolumn{1}{c|}{ Appropriate techniques and data } \\
\hline Surface area and Volume of water/ Growth rate & 1,2 & $\begin{array}{l}\text { Computed from time series satellite images and derived } \\
\text { volume from empirical relation/ change detection }\end{array}$ \\
\hline Seepage through the moraine dam & 2 & Change detection: satellite image time series \\
\hline Supra- and en-glacier channel & 1,2 & $\begin{array}{l}\text { Visual recognition from high resolution satellite image and } \\
\text { supervise image classification }\end{array}$ \\
\hline Risk of ice calving from glacier snout/ice cliff & 2 & Using contour and slope from generated DEM \\
\hline $\begin{array}{l}\text { Rock fall/ice avalanche in the periphery of the } \\
\text { lake }\end{array}$ & 2 & $\begin{array}{l}\text { Visual recognition from satellite images ( (10 m of AVNIR) } \\
\text { with the help of generated slope and contour maps. }\end{array}$ \\
\hline $\begin{array}{l}\text { Freeboard relative to the lake water level } \\
\text { including dam height }\end{array}$ & 2 & $\begin{array}{l}\text { Stereo Satellite image and photogrammetric techniques } \\
\text { (contour and slopes), but field visit is essence. }\end{array}$ \\
\hline $\begin{array}{l}\text { Moraine dam condition (ice-cored/thermokarst, } \\
\text { seepage, steeper slopes etc) }\end{array}$ & 2 & $\begin{array}{l}\text { Visual recognigation from satellite image of } 10 \mathrm{~m} \text { resolution } \\
\text { of AVNIR with the help of generated slope and DEM maps. }\end{array}$ \\
\hline $\begin{array}{l}\text { Complex/compound threats (height of glacier } \\
\text { snout, glacier with deep crevasses, slopes, } \\
\text { orientation, dipping, etc ) }\end{array}$ & 1,2 & $\begin{array}{l}\text { AVNIR satellite data classification, DEM and contour } \\
\text { analysis and visualization techniques, but field visit is } \\
\text { essence. }\end{array}$ \\
\hline
\end{tabular}

\section{GLOF RISK ASSESSMENT/ ANALYSIS}

A methodology to determine the nature and extent of risk by analyzing potential hazards and evaluating existing conditions of vulnerability that could pose a potential threat or harm to infrastructure, people, property, livelihoods and the environment on which they depend. The process of conducting a risk assessment is based on a review of both the technical features of hazards such as their location, intensity, frequency and probability; and also the analysis of the physical, social, economic and environmental dimensions of vulnerability and exposure, while taking particular account of the coping capabilities pertinent to the risk scenarios.

Hence, assessment of GLOF risk is a very difficult and complicated work. Important criteria is the rate and nature of change and these can only be ascertained through subsequent monitoring and re-assessment of the surface area and lake water volume, dam condition, glacier condition and the surroundings of the lake environment such as hanging glaciers, rock fall and snow avalanches etc (triggering mechanism) in a reasonable time interval.

\subsection{EMPIRICAL SCORING SYSTEM FOR GLOF HAZARD POTENTIAL}

Hazard score based on criteria was developed for hazard assessment of glacier lakes by RGSL (1998) during a GLOF study in Bhutan, and tested in Nepal, Peru and Bhutan. RGSL also developed an empirical scoring system (GLOF Source Parameter) for moraine-dammed lake outburst hazard for GLOF Risk assessment of Rongxer basin (RGSL, NEA 2004). The scheme ranks a series of empirically derived criteria that affect magnitude and probability of an outburst. Mostly, similar approach is applied in the present study. Criteria affecting hazard/ score are established based of the decision criteria, scale level and appropriate techniques \& data for evaluating a 
glacier lake's hazard potential in the Imja basin of Nepal Himalayas. Empirical scoring system is more practical and thus helped to rank the magnitude of high-risk to lower orders in terms of glacier lake's hazard potential for moraine-dammed lake. The numbers are given in terms of hazard magnitude for hazard rating. The method ranks a series of empirically derived decision criteria that affect magnitude and probability of an outburst (Table 4).

Here the score is developed, as for example, a lake water volume whose volume is less than $5 \times 10^{6}$ $\mathrm{m}^{3}$ gave a score of 2 for parameter 1 (ID 1); if the range around $5 \times 10^{6}$ to $1.6 \times 107 \mathrm{~m}^{3}$, a score of 10 ; and if much larger $1.6 \times 10^{7} \mathrm{~m}^{3}$ then a score of 40 is given. The same system is applied by different way for each parameter of different ID and the score is added together to give a single value. This value is then compared with an empirical scale indicating potential hazard (Table 5). Higher scores indicate potential of greater hazard and prioritize accordingly. If the total score exceeds 90, then an outburst is considered to be likely at any time.

Table 4: Empirical scoring system for Imja GLOF hazard

\begin{tabular}{|c|l|c|c|c|c|}
\hline ID & \multicolumn{1}{|c|}{ Criteria affecting hazard/ score } & $\mathbf{0}$ & $\mathbf{2}$ & $\mathbf{1 0}$ & $\mathbf{4 0}$ \\
\hline 1 & Surface area and Volume of water & N/A & Low & Moderate & Large \\
\hline 2 & Seepage through the moraine dam & None & Minimum & Moderate & Large \\
\hline 3 & Supra- and en-glacier channel & None & Low & Moderate & Large \\
\hline 4 & Risk of ice calving from glacier snout/ice cliff & N/A & Low & Moderate & Large \\
\hline 5 & Rock fall/ice avalanche in the periphery of the lake & N/A & Low & Moderate & Large \\
\hline 6 & Freeboard relative to the lake water level including dam height & N/A & Low & Moderate & Large \\
\hline 7 & Moraine dam condition (ice-cored/thermokarst, steeper slopes etc) & None & Minimum & Partial & moderate \\
\hline 8 & Complex/compound threats & None & Slight & Moderate. & Large \\
\hline
\end{tabular}

Table 5: Hazard ranking (grading) on the basis of empirical scoring system

\begin{tabular}{|c|c|c|c|c|}
\hline 0 & 45 & 90 & 115 & $\geq 140$ \\
\hline Zero & Minimal & Moderate & High & Very high \\
\hline & & GLOF can occur at any time & & \\
\hline
\end{tabular}

\subsection{GLOF RISK ASSESSMENT OF IMJA GLACIER LAKE}

The kind and combination of criteria used to assess hazard potentials according to different scale levels vary from case to case. Lake area and volume are of primary importance since they define the amount of water available for an outburst. Analysis of Imja glacier lake based on the above empirical scoring system helped to analyze the hazard potential in terms of GLOF risk (Table 6)

It is not possible to make a complete assessment of the GLOF risk without doing more detailed investigation and research work of level 3. The above discussion and score analysis pertained to assess the risk of GLOF from Imja Lake based on the current state-of-knowledge gained from remotely sensed data and previous reports. 
Table 6: Empirical scoring of GLOF hazard

\begin{tabular}{|c|c|c|c|c|c|c|c|c|c|c|c|}
\hline 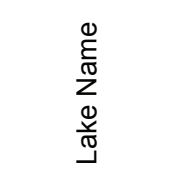 & 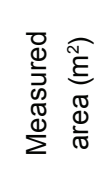 & 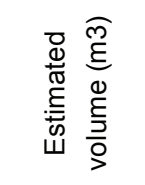 & $\begin{array}{l}\stackrel{0}{E} \\
\frac{3}{0} \\
>\end{array}$ & 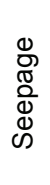 & 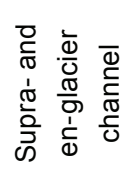 & $\frac{\mathscr{D}}{\frac{D}{\bar{T}}}$ & 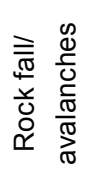 & 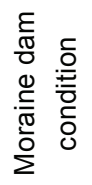 & 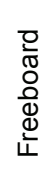 & 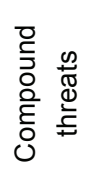 & 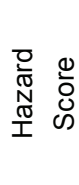 \\
\hline $\begin{array}{l}\text { Imja glacier } \\
\text { lake }\end{array}$ & 959500 & 45609694 & 40 & 0 & 10 & 10 & 0 & 10 & 10 & 10 & 90 \\
\hline
\end{tabular}

It is not possible to make a complete assessment of the GLOF risk without doing more detailed investigation and research work of level 3. The above discussion and score analysis pertained to assess the risk of GLOF from Imja Lake based on the current state-of-knowledge gained from remotely sensed data and previous reports.

\section{CONCLUSION}

Determination of lake storage volume is one of thematic area of glacier lake investigation. Direct depth measurement method or echo-sounding are used to determine lake storage volume. Based on the limited available observed data of similar nature and characteristics of glacier lake, volume storage has been estimated from observed data of depth and area of glacier lakes by applying statistical regression model. The comparison of observed and estimated lake volume showed that there is a difference of $\pm 15 \%$.The functional relationship developed has been applied to Imja glacier lake to estimate lake volume storage from the glacier lake area obtained by remote sensing images.

It is concluded that the lake can be easily detected and monitored by using remotely sensing data. Characteristics of the lake and the dam, and the potential for trigger mechanisms of lake outbursts can be evaluated using specific techniques on different scale levels and derived criteria affecting hazard/score. The result from this study showed that the GLOF risk of the possible outburst from Imja glacier lake is Moderate. It was found that there is a risk of GLOF from Imja Lake. The condition may deteriorate faster in the future and GLOF risk might be higher. It is, therefore, suggested that regular routine investigation of key area of imja glacier laske should be carried out. The results obtained from such investigation would help to update previously collected information and conditions of GLOF risk from Imja Glacier can be analysed. Surrounding of Glacier lake and its environment are found to be rapidly changing due to climate change, Imja glacier lake should be monitored on yearly basis using very-highresolution satellite imagery (e.g. PRISM/IKONOS) and validation of remotely sensed lake area and other physical surrounding condition should be done through field investigation.

It is therefore rational to plan a mitigation strategy against Imja GLOF. The measure has to be a combination of early warning system and lake lowering system. Detail scientific study on geo-technical, glaciological and hydrological aspects and continuous monitoring of Imja lake and its surroundings are essential to gather the in-depth knowledge of the physical situation of the surrounding environment of the lake before deciding on the method to adopt. In view of the hazard potential of glacier lakes in Nepal Himalayas, a systematic application of such remote sensing based methods is recommended. Based on the observations of glacier lake surrounding 
including measured parameters of lake, a criteria based methodology can be established for carrying out the GLOF hazard potential grading which can be used for risk assessment of other Glacier Lakes in similar environment.

\section{REFERENCES}

Baban, S.M.J. 1993. The evaluation of different algorithms for bathymetric charting of lakes using Landsat imagery. International Journal of Remote Sensing, 14: $2263-2274$.

Benny, A.H., and Dawson, G.J. 1983. Satellite imagery as an aid to bathymetric charting in the Red Sea. The Cartographic Journal, 20: $5-16$.

Braun, M. and Fiener, P. 1995 Report on the GLOF Hazard Mapping Project in the Imja Khola/ Dudh Kosi Valley, Nepal, Contribution to the Project"Establishment of a Measuring Service for Snow and Glacier Hydrology in Nepal". Edited by: O.R. Bajracharya (Ag. Project Director) and W.E. Grabs (Team leader, GTZ).

Clague, J.J., and Evans, S.G. 1994. Formation and failure of natural dams in the Canadian Cordillera. Geological Survey of Canada Bulletin 464, Ottawa. Costa, J.E., and Schuster, R.L. 1988. The formation and failure of natural dams. Geological Society of America Bulletin, 7: 10541068.

DHM, 1999. Monitoring the Growth Rate of Imja Glacier Lake. Kathmandu

DHM, 2001. Final Report on Preliminary Analysis for the Preparation Proposal for
Minimization of Potential GLOF Hazard from Imja Glacier Lake.

Dwivedi, S.K., Acharya, M.D. and Simard, R. 2000. The Tam Pokhari Glacier Lake outburst floods of 3 September 1998. Journal of Nepal Geological Society. 22. 539-546.

Fuji, Y. and Higuchi, K., 1976. Ground temperature and its relation to permafrost occurences in the Khumbu Region and Hidden Valley. Seppyo, 38: 125-128.

Fujita, K., Sakai, A., Nuimura, T., Yamaguchi, S. and Sharma, R. R. 2009. Recent changes in Imja Glacier Lake and its damming moraine in the Nepal Himalaya revealed by in situ surveys and multi-temporal ASTER imager. IOP PUBLISHING, ENVIRONMENTAL RESEARCH LETTERS (Environ. Res. Lett. 4 (2009) 045205, 7pp), doi:10.1088/17489326/4/4/045205.

Grabs, W.E. and Hanisch, J. 1993. Objectives and prevention methods for glacier lake outburst floods (GLOFs). In Snow and Glacier Hydrology. IAHS publication No. 218. Edited by G.J. Young. 319-330.

Hanisch, J., Koirala, A., and Grabs, W.E. 1996. Ausbrüche von Gletscherseen in Nepal und ihre mögliche Verhinderung. Zeitschrift für angewandte Geologie, 42: 8-13.

Huggle, C. Kääb, A. Haeberli, W. Paul, P. and Teysseire, P. 2002. Remote sensing based assessment of hazards from glacier lake outbursts: a case study in the Swiss Alps, Can. Geotech. J. 39: 316-330. 
ICIMOD, 2001. Inventory of glaciers, glacier lakes and glacier lake outburst floods, monitoring and early warning system in Hindu Kush-Himalaya Region, Nepal, ICIMOD/UNEP.

ICIMOD, UNEP, CAREERI, BHT, APN, START. 2004. Inventory of Glaciers, Glacier Lakes, and the identification of potential glacier lake outburst folds (GLOFs) affected by global warming in the mountains of Himalayan region, Poiqu (Bhote-Sun Koshi) and Rongxer (Tama Koshi) Basins of Tibet Autonomous Region, PR China.

Ives, J.D. 1986. Glacier lake outburst floods and risk engineering in the Himalaya. ICIMOD Occasional Paper 5, 42 pp.

Jakob, M. 1992. Blockgletscher in Khumbu Himalaya, Nepal. Master Thesis, Geographischen Institut der RuprechtKarls-Universiät, 123pp.

Kääb A. 1996. Photogrammetrische Analyse zur Früherkennung gletscherund permafrostbedingter Naturgefahren im Hochgebirge. Mitteilungen der VAW/ ETHZ 145, Zürich.

LIGG/WECS/NEA 1988. Report on First Expedition to Glaciers and Glacier Lakes in the Pumqu (Arun) and Poiqu (BhoteSun Koshi) river basins, Xizang (Tibet), China, Sino-Nepalese Investigation of Glacier Lake Outburst Floods in the Himalaya. Beijing, China: Science Press

Meon, G., and Schwarz, W. 1993. Estimation of glacier lake outburst flood and its impact on a hydro-project in Nepal. In Proceedings of the International Symposium on Snow and Glacier Hydrology, Kathmandu.16-21 November 1992. Edited by G. J. Young, International Association of Hydrological Sciences, Wallingford, England. IAHS Publication No. 218, pp. 331-340.

Pietroniro, A., and Leconte, R. 2000. A review of Canadian remote sensing applications in hydrology, 1995-1999. Hydrological Processes, 14: 1641-1666.

RGSL, NEA. 2004. Consulting Services for Feasibility Study of Upper Tama Koshi Hydroelectric Project. Appendix D: Glacier Lake Outburst Flood (GLOF) Risk Assessment Study. Unpublished Technical Report J03170 Report v1.0, July 2004, Reynolds Geo-Sciences Ltd, Mold, UK.

Richardson, S.D., and Reynolds, J.M. 2000. An overview of glacier hazards in the Himalayas. Quaternary International, 65/66: 31-47.

Sakai, A. 1995. Thermal Characteristics of a glacier lake in Nepal Himalaya: Master's thesis submitted by, Graduate School of Environmental Earth Science, Hokkaido University, Japan.

Shrestha, A. B., 2007. Glacier Lake Outburst Flood Vulnerability Assessment. Himalayan Wetlands: Risk, Challenges and Opportunities, pp 27-29. Changwon: Ramsar Wetlands Center Korea.

Shirahata, S., 1983. Nepal Himalaya. allied Publishers Private Ltd., Bombay. 233pp. 
Teysseire, P. 1999. Gefährliche Gletscherseen im Wallis. In Proceedings CENAT (Natural Hazards Competence Centre (Switzerland))Fachtagung Naturgefahren: Gletscher und Permafrost, Zurich, 29 March 1999, pp. 15-18.

Vallon, M. 1989. Evolution, water balance, potential hazards and control of a pro-glacier lake in the French Alps. Annals of Glaciology, 13: 273-278.

Vuichard, D., and Zimmermann, M. 1987. The 1985 catastrophic drainage of a morainedammed lake Khumbu Himal, Nepal: cause and consequences. Mountain Research and Development, 7: 91-110.

Watanabe, T., Ives, J.D. and Hammond, J.E., 1994. Rapid growth of a glacier lake in Khumbu Himal, Himalaya: Prospects for a catastrophic flood. Mountain Research and Development, 14: 329-340.

WECS (1987b) Study of Glacier Lake Outburst Floods in the Nepal Himalayas, Phase I,Interim Report, May, 1997, WECS Report No. 4/1/200587/1/1, Seq. No. 251. Kathmandu, Nepal: WECS
WECS, 1991. Preliminary Work Report on Glacier Lake Outburst Flood in the Nepal Himalaya, WECS Report No. 4/1/291191/1/1, Seq. No. 387, August 1991, Kathmandu.

WECS . 1999. Water and Energy commission Secretariat Bulletin, vol 1, No 1 \& 2, April 1999, pp 11-13)

XU Daoming and FENG Qinghua. 1994. Dangerous glacier lakes and their outburst features in the Tibetan Himalayas, Bulletin of Glacier Research 12 (1994) 1-8, Data Center for Glacier Research, Japanese Society of Snow and Ice.

Yamada T., 1998. Glacier Lakes and Their Outburst Floods in the Nepal. Data Center for Glacier Research, Japanese Society of Snow and Ice. Monograph No. 1. March 1998. Tokyo.

Yongjian, D., and Jingshi, L. 1992. Glacier lake outburst flood disasters in China. Annals of Glaciology， 16: 180-184 